\title{
UJI ANTIMITOSIS EKSTRAK ETANOLIK KLIKA SIRSAK (Annona muricata L.) TERHADAP SEL TELUR LANDAK LAUT (Tripneustes gratilla L.) TERFERTILISASI
}

\author{
Niken Pratiwi Liambo1, Abd. Malik, dan Aktsar Roskiana Ahmad \\ Fakultas Farmasi, Universitas Muslim Indonesia \\ niken_weaslay@yahoo.com
}

\begin{abstract}
Soursop belongs to Annonaceae family. In the traditional medicine has been as anticancer, antivirus, wound healing, lowering uric acid levels. This study aims to determine the $I_{80}$ value extract ethanolic of soursop bark to sea urchin egg (Tripneustes gratilla L.) fertilized. Dryed sample extracted by maceration method using ethanol solvent. Retrieved rendamen extract as much as 2,525\%. Based on qualitative test chemical components that extract ethanolic of soursop bark contain tannins, saponins, alkaloids and flavonoids. Antimitotic test conducted on extract ethanolic of soursop bark (A.muricata) obtained by looking at the sea urchin egg cell inhibition (Tripneustes gratilla $\mathrm{L}$.) to calculate $I C_{80}$ values by probit analysis method. Antimitotic test results showed that the extract ethanolic of soursop bark (A. muricata) as an antimitotic active with $I_{80}$ values of 1,56 $x$ $10^{-3} \mathrm{mg} / \mathrm{ml}$. Although the potential is lower than that of vincristine inhibit $80 \%$ of eggs fertilized with Tripneustes

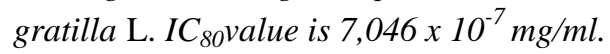

Keywords: Annona muricata L., antimitotic, Tripneustes gratilla $\mathrm{L}$.

\section{PENDAhuluan}

Secara lebih detail, definisi jamu atau obat tradisional adalah bahan atau ramuan bahan yang berupa bahan tumbuhan, bahan hewan, bahan mineral, sediaan sarian (galenik), atau campuran dari bahan tersebut yang secara turun-temurun telah digunakan untuk pengobatan berdasarkan pengalaman. Sesuai dengan peraturan perundangundangan yang berlaku, obat tradisional dilarang menggunakan bahan kimia hasil isolasi atau sintetik berkhasiat obat yang sering disebut dengan bahan kimia obat (BKO) (Yuliarti, 2010).

Masyarakat Indonesia sudah mengenal dan menggunakan tumbuhan berkhasiat obat sebagai salah satu upaya penanggulangan masalah kesehatan yang dihadapi. Hal ini telah dilakukan jauh sebelum pelayanan kesehatan formal dengan obat-obatan modern menyentuh masyarakat pengetahuan tentang tumbuhan obat merupakan warisan budaya bangsa turun temurun.

Bioaktivitas tanaman sangat dipengaruhi oleh kandungan senyawa kimia yang terdapat di dalamnya. Perbedaan kandungan senyawa kimia yang ada dapat menunjukkan perbedaan aktivitas farmakologis dari tanaman yang bersangkutan (Zuhud, 2011).

Pada tahun 1995 penelitian dimulai oleh Sastrodihardjo dan Lauglin tentang khasiat daun sirsak dalam mengatasi sel kanker di Indonesia. Hasil penelitian tersebut menemukan beberapa senyawa aktif yang termasuk kedalam annonaceous acetogenins. Beberapa senyawa turunan asetogenin yang ditemukan adalah asetogenin murikatosin $\mathrm{A}$, murikatosin B, annonasin A, transisoannonasin, annonasin-10-one, dan murikatosin. Senyawasenyawa aktif tersebut ditemukan didalam daun dan batang sirsak yang ternyata mampu membunuh beragam sel kanker (Zuhud, 2011).

Pengujian pembelahan sel telur landak laut dilakukan dengan mengamati penghambatan pembelahan sel telur oleh suatu senyawa, dimana secara normal pembelahan sel telur tersebut terjadi dengan cepat. Keuntungan dari metode ini adalah pengerjaannya yang relatif cepat, tidak memerlukan kultur sel serta peralatan dengan metode khusus seperti sel kanker, embrio landak laut juga mempunyai sensitifitas selektif terhadap obat sehingga pengujian dengan cara ini menjadi metode yang layak bagi penentuan bahan yang akan dievaluasi lebih lanjut (Mclaughlin, 1991).

Studi penghambatan pada perkembangan sel zigot landak laut merupakan salah satu model yang digunakan untuk mendeteksi aktivitas sitotoksik, teratogenik, dan antineoplastik dari senyawa baru. Sel zigot landak laut memiliki sensitivitas selektif terhadap obat dan mengalami tahapan pembelahan seperti halnya sel kanker, sehingga banyak digunakan dalam penelitian antikanker. Misalnya untuk melihat pengaruh suatu senyawa dalam menghambat laju pembelahan dan pertumbuhan sel yang disebut sebagai sifat antimitotik atau sitotoksik.

\section{METODE PENELITIAN}

A. Pengabilan dan Pengolahan Sampel

Sampel Klika Sirsak (Annona muricata L.) dikumpulkan pada pagi hari pukul 10.00 dengan cara 
memotong klika dari cabang dan batang utamanya.Sampel yang digunakan diambil darikota Kendari Provinsi Sulawesi Tenggara.

Klika Sirsak (Annona muricata L.) yang telah diperoleh dicuci bersih dari kotoran yang melekat dengan menggunakan air setelah itu dianginanginkan. Setelah kering dipotong-potong kecil kemudian dihaluskan, dan siap untuk diekstraksi.

\section{B. Metode Ekstraksi}

Sampel klika sirsak (Annona muricata L.) dimasukkan kedalam wadah maserasi, lalu ditambahkan pelarut etanol hingga simplisia tersebut terendam, dibiarkan selama 3 hari dalam bejana tertutup dan terlindungi dari cahaya matahari langsung sambil diaduk secara periodik, setelah 3 x 24 jam dilakukan penyaringan untuk diperoleh ekstrak metanolcair. Hasil penyarian yang diperoleh kemudian diuapkan dengan menggunakan rotavapor.

\section{Pembuatan Bahan dan Pengujian Sampel}

a. Pembuatan Larutan KCI $10 \%$ b/v.

Sebanyak 10 gram KCI dimasukkan kedalam labu tentukur $100 \mathrm{ml}$ lalu ditambah air suling sedikit demi sedikit, sambil dikocok dan dicukupkan volumenya sampai $100 \mathrm{ml}$.

\section{b. Penyiapan air laut bersih untuk media}

Air laut bersih yang digunakan sebagai media dan untuk membersihkan media uji dengan cara menyaring dengan menggunakan sinter glass sehingga bebas dari protozoa.

c. Proses penyiapan sel telur dan sperma bulu babi

Penyiapan sel telur dan sperma bulu babi mengacu pada cara Rahman 2005 dan Militao et.al. 2007 dengan beberapa modifikasi adapun langkahnya yaitu sebagai berikut:

1. Landak laut jantan dan betina yang dewasa secara seksual diinduksi 3,0 $\mathrm{ml}$ dengan penyuntikan $\mathrm{KCl} 10 \%$.

2. Sperma berwana putih dari landak laut jantan dan sel telur berwarna kuning dari landak laut betina dikumpulkan dalam gelas kimia secara terpisah.

3. Fertilisasi dilakukan dengan cara $1 \mathrm{ml}$ sperma dan $4 \mathrm{ml}$ sel telur difertilkan dalam gelas kimia yang berisi $50 \mathrm{ml}$ air laut bebas protozoa.

4. Embrio- embrio tersebut diinkubasi $2-3$ jam. Inkubasi dilaksanakan pada suhu $14^{0}$ atau $15^{\circ} \mathrm{C}$, disertai dengan pengadukan/pergerakan agar tidak terjadi pengendapan, untuk meningkatkan adanya kontak hambatan dan untuk memastikan distribusi sampel yang efisien.

5. Perlakuan yang sama dilakukan terhadap kontrol air laut dan kontrol positif.

6. Sampel ekstrak etanol masing-masing ditimbang sebanyak $10 \mathrm{mg}$ kemudian ditambahkan dengan air laut sebanyak $10 \mathrm{ml}$ sehingga diperoleh konsentrasi $1000 \mu \mathrm{g} / \mathrm{ml}$ sebagai stok. Larutan stok dipipet sebanyak 10,100, dan $1000 \mu \mathrm{l}$ kedalam tabung Eppendrof yang masing- masing telah berisi $890 \mu \mathrm{l}$ dan $800 \mu$ lair laut bebas protozoa lalu ditambahkan $100 \mu$ l larutan yang berisi zigot yang diperoleh sebanyak $100 \mu \mathrm{l}$ adalah 10,100, dan $1000 \mu \mathrm{g} / \mathrm{ml}$. Selanjutnya disimpan pada suhu $15-20^{\circ} \mathrm{C}$ dengan diselingi pengocokan. Pengamatan yang membelah dilakukan setelah 3 jam inkubasi. Formalin sebanyak 1 tetes ditambahkan.

7. Penghambatan pembelahan diamati dari populasi acak di bawah mikroskop cahaya setelah waktu inkubasi 2-3 jam. Jika 80 hingga $100 \%$ penghambatan pembelahan

8. Hasilnya dinyatakan sebagai persentase (jumlah sel membelah dibagi dengan jumlah total telur dikali seratus) relatif terhadap kontrol diperlakukan pelarut. Pengamatan dilakukan dengan menghitung jumlah sel yang terhambat pembelahannya dan akan dihitung sebagai $\mathrm{IC}_{80}$.

d. Pembuatan pembanding

1. Kontrol negatif

Kontrol negatif yang digunakan yaitu air laut bebas protozoa sebanyak $900 \mu \mathrm{l}$ ditambahkan $100 \mu \mathrm{l}$ zigot.

\section{Kontrol positif}

Pembanding menggunakan vinkristin dengan konsentrasi $0,01 \mu \mathrm{g} / \mathrm{ml}, 0,1 \mu \mathrm{g} / \mathrm{ml}$, dan $1 \mu \mathrm{g} / \mathrm{ml}$. Untuk membuat konsentrasi $0,01 \mu \mathrm{g} / \mathrm{ml}$ dipipet $0,1 \mu \mathrm{l}$ dari larutan stoknya lalu ditambahkan $100 \mu \mathrm{l}$ zigot dan $899,9 \mu \mathrm{l}$ air laut bebas protozoa. Untuk membuat konsentrasi $0,1 \mu \mathrm{g} / \mathrm{ml}$ dipipet $1 \mu \mathrm{l}$ dari larutan stoknya lalu ditambahkan $100 \mu$ zigot dan 899 air laut bebas protozoa. Untuk membuat konsentrasi $1 \mu \mathrm{g} / \mathrm{ml}$ dipipet $10 \mu \mathrm{l}$ dari larutan stoknya lalu ditambahkan $100 \mu \mathrm{l}$ zigot dan $890 \mu \mathrm{l}$ air laut bebas protozoa. Dilakukan replikasi 3 kali untuk tiap sampel uji, kontrol dan pembanding. Selanjutnya disimpan pada suhu 15$20^{\circ} \mathrm{C}$ dengan diselingi pengocokan. Pengamatan yang membelah dilakukan setelah 2 jam inkubasi. 


\section{HASIL DAN PEMBAHASAN}

A. Hasil Penelitian

Tabel 1. Hasil perhitungan $\mathrm{IC}_{50}$ dan $\mathrm{IC}_{80}$ menurut metode grafik probit Log konsentrasi dari ekstrak etanolik klika sirsak (Annona muricata L.) dan vinkristin.

\begin{tabular}{cccccc}
\hline Sampel & $\begin{array}{c}\text { Log } \\
\text { Konsentrasi } \\
(\mathbf{x})\end{array}$ & $\begin{array}{c}\text { Probit } \\
(\mathbf{y})\end{array}$ & Pers. Garis & $\begin{array}{c}\mathbf{I C 5 0} \\
(\mathbf{m g} / \mathbf{m L})\end{array}$ & $\begin{array}{c}\mathbf{I C 8 0} \\
(\mathbf{m g} / \mathbf{m L})\end{array}$ \\
\hline Ekstrak etanolik & 1 & 5,47 & $\mathrm{y}=4,60+0,79 \mathrm{x}$ & $5 \times 10^{-4}$ & $1,56 \times 10^{-3}$ \\
klika sirsak & 2 & 6,04 & & & \\
& 3 & 7,05 & & & \\
Vinkristin & -2 & 6,41 & $\mathrm{y}=7,29+0,46 \mathrm{x}$ & $1,051 \times 10^{-5}$ & $7,046 \times 10^{-4}$ \\
& -1 & 6,75 & & & \\
& 0 & 7,33 & & & \\
\hline
\end{tabular}

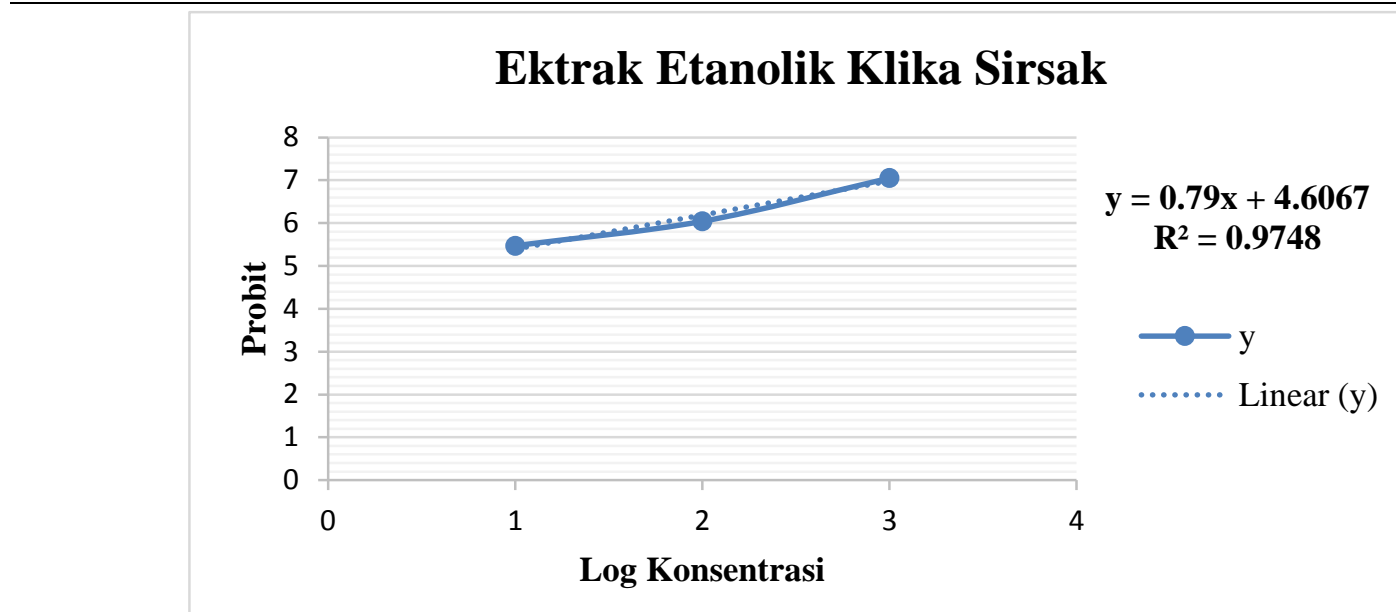

Gambar 1. Grafik hubungan antara log konsentrasi terhadap probit ekstrak etanol klika sirsak (Annona muricata L.)

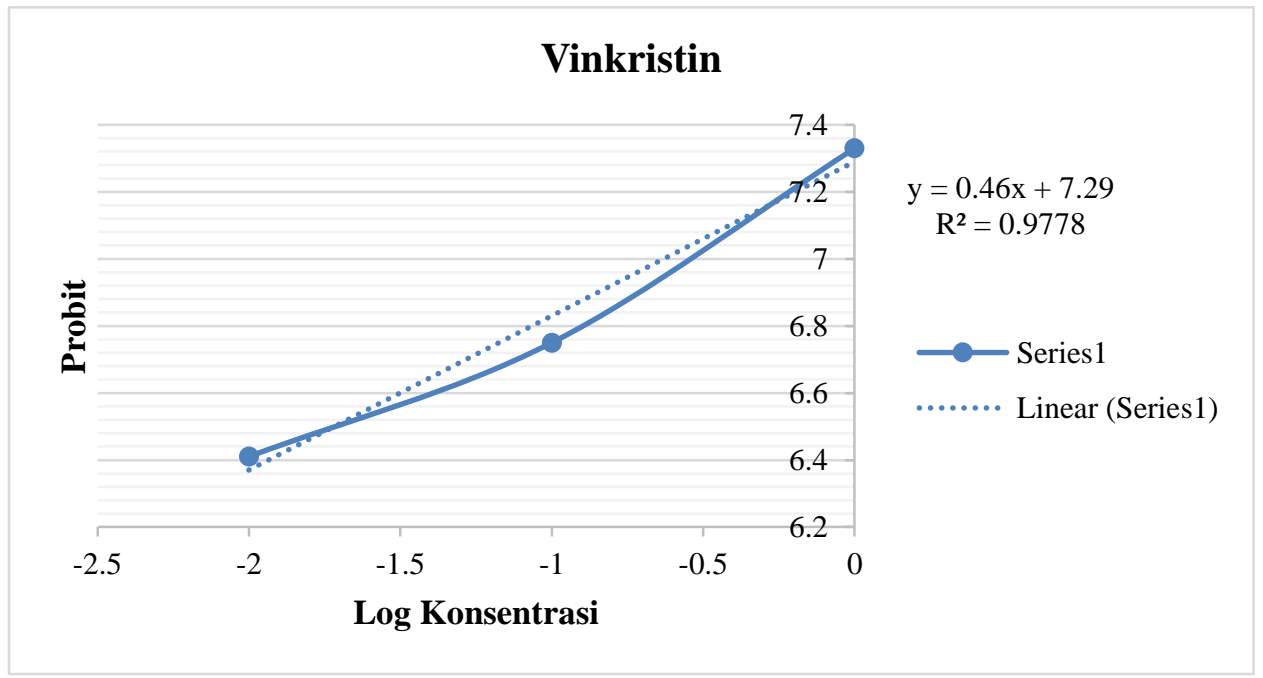

Gambar 2. Grafik hubungan antara log konsentrasi terhadap probit kontrol positif (obat vinkristin)

\section{B. Pembahasan}

Penelitian ini menggunakan klika sirsak (Annona muricata L.) yang berasal dari provinsi Sulawesi Tenggara Kota Kendari. Tanaman sirsak (Annona muricata L.) mengandung flavonoid, alkaloid, saponin dan tannin yang dimanfaatkan sebagai pengobatan kanker (Rahmadi, 2012). Sampel terlebih dahulu dipotong - potong kecil kemudian dikeringkan dengan cara diangin - anginkan diruang terbuka. Maksud dari pengeringan yaitu untuk 
mencegah terjadinya reaksi enzimatis, dimana reaksi ini terjadi jika simplisia mengandung air lebih dari 10\% (Ditjen POM, 1995).

Pengujian antimitosis dengan menggunakan sel telur landak laut dimana studi penghambatan pada perkembangan sel zigot landak laut merupakan salah satu model yang digunakan untuk mendeteksi aktivitas sitotoksik, teratogenik, dan antineoplastik dari senyawa baru.Sel zigot landak laut memiliki sensitivitas selektif terhadap obat dan mengalami tahapan pembelahan seperti halnya sel kanker, sehingga banyak digunakan dalam penelitian antikanker. Misalnya untuk melihat pengaruh suatu senyawa dalam menghambat laju pembelahan dan pertumbuhan sel yang disebut sebagai sifat antimitotik atau sitotoksik (Johannes, 2013).

Alasan penggunaan $\mathrm{KCl} 10 \%$ yaitu karena larutan ini bersifat hipotonis sehingga mampu memecahkan dinding sel dari landak laut tersebut. Hal itulah yang mengakibatkan sel sperma dan sel telur dapat keluar. Air laut bebas protozoa digunakan karena jika dalam air laut terdapat protozoa, maka protozoa tersebut memakan sel sperma dan sel telur dari landak laut. Formalin ditambahkan dengan tujuan untuk menghambat pembelahan sel dari landak laut setelah diberi perlakuan dengan penambahan sampel dan setelah didiamkan, hal ini dilakukan agar tidak mengganggu dalam pengamatan (Nurul, 2012).

Hasil penelitian yang diperoleh menunjukkan bahwa ekstrak etanolik klika sirsak (Annona muricata L.) konsentrasi $10 \mu \mathrm{g} / \mathrm{ml}, 100 \mu \mathrm{g} / \mathrm{ml}$ dan $1000 \mu \mathrm{g} / \mathrm{ml}$ dapat menghambat pembelahan sel telur Tripneustes gratilla Linn dengan penghambatan ratarata sebesar 68,44\%; 85,87\%; dan 98,85\%. Data tersebut memperlihatkan bahwa efek antimitosis akan menurun pada konsentrasi yang lebih rendah, hal ini disebabkan karena semakin kecil konsentrasi ekstrak yang digunakan maka semakin kecil pula kandungan senyawa kimia yangmenghambat pembelahan sel telur landak laut. Seperti halnya dengan vinkristin sebagai pembanding positif dengan konsentrasi $0,01 \mu \mathrm{g} / \mathrm{ml} ; 0,1 \mu \mathrm{g} / \mathrm{ml}$; dan $1 \mu \mathrm{g} / \mathrm{ml}$ dengan penghambatan rata-rata sebesar $92,01 \%$, $96,33 \%$ dan $99,23 \%$. Jadi, berdasarkan nilai persen penghambatan terhadap sel telur landak laut maka diketahui bahwa vinkristin sebagai kontrol positif memiliki nilai persen penghambatan yang paling besar dibandingkan dengan nilai persen penghambatan dari ekstrak etanol klika sirsak.

Hasil analisi probit menunjukkan bahwa ekstrak klika sirsak memiliki nilai IC80 sebesar 1,56 $\mu \mathrm{g} / \mathrm{ml}$. Hasil tersebut menunjukkan bahwa tanaman klika sirsakdari ekstrak etanol memiliki aktivitas antimitosis dengan menggunakan metode penghambatan sel telur landak laut. Hal ini berdasarkan penelitian sebelumnya yaitu suatu bahan dinyatakan aktif jika penghambatan sel terjadi $\left(\mathrm{IC}_{80-}\right.$ ${ }_{100}$ ) dicapai pada konsentrasi lebih rendah dari 16 $\mathrm{mg} / \mathrm{ml}$. (Rahman et al, 2001). Hasil yang diperoleh potensinya lebih rendah jika dibandingkan dengan vinkristin yang memiliki nilai $\mathrm{IC}_{80}$ sebesar 7,046 x $10^{-4} \mu \mathrm{g} / \mathrm{ml}$.

Berdasarkan hasil penelitian ini senyawa yang memiliki potensi sebagai antimitosis pada ekstrak klika sirsak adalah Annonaceus acetogenin. Hal ini dikaitkan dengan penelitian lain yang membuktikan khasiat kandungan asetogenin bahwa pada kulit batang sirsak mengandung satu asetogenin, solamin, dan dua triterpenoid, stigmasterol dan sitosteral. Annonaceous acetogenin telah ditemukan lebih dari 400 jenis strukturnya dan terus berkembang sampai sekarang. Pada sirsak khususnya, telah ditemukan 50 jenis annonaceous acetogenin dari biji, kulit batang, daging buah, dan daun sirsak (Wijaya, 2012). Demikian pula dengan Zuhud, 2011 menyatakan bahwa diberbagai negara yang dibiayai oleh Lembaga Institut Kanker Nasional, Amerika Serikat dimana dari penelitian tersebut didapatkan hasil sebanyak 20 tes laboratorium menemukan bahwa daun dan batang Annona muricata L. memiliki sitotoksisitas terhadap sel kanker.

\section{KESIMPULAN}

Berdasarkan hasil penelitian dapat disimpulkan bahwa ekstrak etanol klika sirsak (Annona muricata L.) mempunyai potensi sebagai antimitosis dengan nilai C80 dari ekstrak etanol klika sirsak (Annona muricata L.) sebesar 1,56 x 10 $\mathrm{mg} / \mathrm{ml}$.

\section{DAFTAR PUSTAKA}

Adjie, S., 2011, Dahsnyatnya Sirsak Tumpas Penyakit. Pustaka Bunda: Jakarta.

Anderson, J. E., Goetz, C. M,. 1991. A Blind Comparison Of Simple Benzch Top Bioassay And Human Tumor Cell Cytotoxicities As Antitumor Prescreens, phytochem Anal., volume 2.

Arthur C. Guyton dan John E. Hall. 2007. Buku Ajar Fisiologi Kedokteran. Penerbit Buku Kedokteran EGC: Jakarta

Aslan, L.M., 2005. Bulu babi, Manfaat dan pembudidayaanya. UNHALU Press: Kendari

Barnes R.D., 1987. Invertebrate zoology $5^{\text {th }}$ Ed. Fort Worth, TX: Hacourt Brace Jovanovich College Publishers.

Behrman, Kliegman. \& Arvin. 2000. Nelson Ilmu Kesehatan Anak Edisi: 15, vol 2. Jakarta: EGC.

Campbell, Neil A., Jane B. Reece, Lawrence G. Mitchell. 1999. Biology, $5^{\text {th }}$ Edition. 
Terjemahan oleh Rahayu Lestari. 2002. Elangga. Jakarta

Casarett, L.J., dan Doul J. 1975. Toxicology, The Basic Sceine of Poison, First Edition, Mac Millan Publishing, Co, Inc, Newyork.

Ciulei J., 1984. Metodologi for analisa of vegetables and Drugs. Faculty of Pharmacy, Bucharest Rumania, 11-26 (Online)(http://www.berkalahayati.org/index

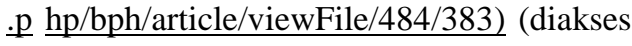
11 september 2013)

Darwis, D. 2000. Teknik dasar Laboratorium dalam Penelitian Senyawa Bahan Alam Hayati. Workshop Pengembangan Sumberdaya Manusia di dalam Bidang Kimia Organik Bahan Alam Hayati. Padang: FMIPA Universitas Andalas.

Ditjen POM. 1986. Sediaan Galenik. Jakarta: Departemen Kesehatan Republik Indonesia, Jakarta.

Fadhilla, R., 2013. Potensi Tumbuhan Lumut Sebagai Sumber Baru Antibakteri. (Online). (http://pustakaku.net/sciencetechnology-news/potensi-tumbuhan- lumutsebagai-sumber-baru-ntibakteri. Diakses tanggal 05 Oktober 2013

Gajalaksmi, Vijayalakshmi, and Rajeswari, D., 2012. International Journal of Pharmacy and Pharmaceutical Sciences. Academic Sciences, vol 4, Issue 2.

Herbal Secret of the Rainforest, Graviola, www.graviola.org/cgi/gpp.cgi?

ITIS (Integrated Taxonomic Information System. 2013. Hibiscus sabdariffa (L>) Skeels (online).http://www.itis.gov/serulet/singlerpt 2 single Rpt?search topic $=$ TSN\& search balue $=505419$.diakses tanggal 18 September 2013.

Johanes.2013. Aktivitas Antimitotik B- Sitosterol Isolat Dari Hydroid Aglaophenia Cupressina Lamoureoux Terhadap Pembelahan Awal Sel Zigot Bulu Babi Tripneustes Gratilla Linn. Jurusan Biologi fakultas MIPA Universitas Hasanuddin: Makassar.

Juhaeni, Radi. 2011. Budi Daya Sirsak dan Pemanfaatannya. Penerbit Kanisius, Yogyakarta.

Loomis, T. A., 1978. Toksisitas Dasar, edisi III, penerjemah Imono Argo, IKIP Semarang Press.

Naziya. 2006. Pengaruh Pemberian Ekstrak Tapak Dara (Catharanthus roseus) Dan Temulawak (Curcuma xanthorhiza) Terhadap Gambaran Histopatologi Kelenjar Payudara Mencit C3H Yang Diinokulasi
Adenocarcinoma Mammae: Semarang

Nurhasanah. 2009. Uji Antimitosis Ekstrak Etanol Sangsri (Celosia argentea L.) dengan Metode Penghambatan Pembelahan Sel Telur Bulu Babi. Fakultas Farmasi Universitas Muslim Indonesia: Makassar.

Nurul. 2012. Uji Antimitosis Pada Sel Bulu Babi (Tripenustes gratilla). Universitas Hasanuddin: Makassar

Mc. Laughlin, J.L., 1991. Grown Gall Tumours on Potato Disc and Brine shrimp lethality test : Two Simple Bioassay for Higher Plant Screening and Fractionation, Methods in Plant Biochemistry, Assay for Bioactivity, Vol.6, London: AcademicPress

Meyer, B. N., Ferrigni, N. R., Putman, J. E., Jacbs en, L. B., Nicols,. D. E., and Mclaughlin, J. L. 1982. Brine Shrimp: A Comvenient general Bioassay For Active Plant Constituents. Plant Medica.

Militao, C. G. Gardenia, Savio. M. Pinheiro, Ivana. N. F Dantas, Claudia Pessoa, Manoel de Moraes. 2007. Bioassay-guided fractionation of pterocarpans from roots of Harpalyce brasiliana Benth, Fortaleza, Ceara, Brazil

Mishra, S., Ahmad, S., Kumar, N and Sharma, B.K, 2013. Annona muricata (The cancer killer): A review. The Global Journal of Pharmaceutical Research Vol. 2(1).

Mukono, H. J. 2005. Toksikologi Lingkungan. Airlangga University Press, Surabaya.

Nurjanah, S., and Fathia, S. 2011. Antimicrobial Activity Of Ginger Extract (Zingiber officinale Roscoe) Against Several Pathogen Bacterial.Penerbit Institut Pertanian Bogor; Jawa Barat.

Pasaribu, S.P. Mei 2008.Uji Bioaktivitas Metaboliut Sekunder Dari Daun Tumbuhan Babadotan (Ageratumconyzoides L.). Jurnal Kimia Mulawarman. Vol. 6, No.2

Pujiati, I., S. Ningsih, S. Palupi dan Tri Windono, 2002.Uji toksisitas terhadap larva Artemia salina Leach dari fraksi n-heksan, khloroform, etil asetat dan air ekstrak etanol rimpang temumanga (Curcuma mangga VaL).Prosiding Seminar Nasional Tumbuhan Obat Indonesia XXI. Universitas Surabaya, Surabaya.

Pryanto, 2009. Toksikologi Mekanisme, Terapi Antidotum dan Penelitian Resiko. Lembaga Studi dan Konsultasi Farmakologi (Leskonfi). Depok.

Rahmadi, Wijaya. 2012. Potensi Nanopartikel Magnetik Ekstrak Daun Sirsak Sebagai Obat Antikanker 
Rahman, A., Choudhary MI, Thomsen WJ. 2005. Bioassay Techniques for Drug Development. Amsterdam, The Netherlands: Harwood Academic

Rahayu, et al., 2012.Ekstrak Daun Sirsak (Annona muricata.L) sebagai Antioksidan pada Penurunan Kadar Asam Urat Tikus Wistar. Jurusan Kimia Fakultas MIPA Universitas Udayana: Bali.

Rosenda, E. H. Anandita dan Suhardjono. 2009. Uji Toksisitas Ekstrak Etanol Daun Kemangi (Ocimun sanctum Linn). Terhadap Larva Artemia salina Leach Dengan Metode Brine Shrimp Lethality Test (BST). Majalah Faramasi Indonesia, Semarang.

Sloane, Ethel. 2004. Anatomi Fisiologi untuk Pemula. EGC: Jakarta

Surianto, 2011. Dashatnya Sirsak Tumpas Penyakit. Pustaka Bunda: Jakarta.

Soemirat, Juli. Dkk. 2009. Toksikologi Lingkungan. Gadja Mada University Press, Yogjakarta.

Tobo, F. 2001. Buku Pengantar Laboratorium Fitokimia I. Laboratorium Fitokimia Jurusan Farmasi Fakultas MIPA Universitas Hasanuddin, Makassar.

Wijaya, M., 2012. Ekstraksi Annonaceous acetogenin dari daun sirsak, (Annona muricata Linn) sebagai senyaa bioaktif antikanker. (Skripsi). Jakarta: Universitas Indonesia.

Wilmoth, J. H., 1967. Biology of Invertebrate. Prentice-Hall, Inc. New Jersey

Zuhud, E. A. 2011. Bukti Kedahsyatan Sirsak Menumpas Kanker. Agromedia Pustaka: Jakarta 